\title{
THE DEMOCRATIC ALLIANCE AND THE ROLE OF OPPOSITION PARTIES IN SOUTH AFRICA
}

\author{
Shauna Mottiar \\ Shauna Mottiar is Senior Lecturer, Development Studies, \\ School of Built Environment and Development Studies, \\ University of KwaZulu-Natal \\ e-mail: Mottiar@ukzn.ac.za
}

\begin{abstract}
In the 2014 election the Democratic Alliance (DA) strengthened its electoral support nationally as well as in the Western Cape province, where it governs. It gained over a million new national votes, increasing its total from 2945829 in 2009 to 4091548 in 2014. It also unseated the Inkatha Freedom Party (IFP) as official opposition in KwaZulu-Natal and became the official opposition in the Eastern Cape, Mpumalanga, Northern Cape and Free State, while strengthening its opposition status in Gauteng from $21.86 \%$ of the vote in 2009 to $30.78 \%$ in 2014. In the Western Cape it gained $59.38 \%$ of the vote, an increase from $51.46 \%$ in 2009 . This article considers whether the DA's 2014 electoral gains suggest a strengthening of opposition politics in South Africa. It focuses on whether the DA meets the obligations of an opposition party with regard to providing an institutional space for counter-political elites to organise and providing a viable alternative to the ruling party together with facilitating debate over political issues and public policy while also performing an oversight role.
\end{abstract}

\section{INTRODUCTION}

In what has largely been referred to as a party-dominant system, with the African National Congress (ANC) gaining the majority of South African electoral support in five consecutive democratic elections, the Democratic Alliance (DA) has proved to have significant staying power, entrenching its electoral support. In the 2014 elections the DA won $22.23 \%$ of the national vote, a significant increase from its original $1.73 \%$ in 1994. A survey of its election results since 1994, depicted in Table 1, reveal the steady growth of its support. 
Table 1

DA National Election Results 1994-2014

\begin{tabular}{|l|c|c|c|}
\hline Year & Number of votes & \% of votes & Seats in Parliament \\
\hline 1994 & 338426 & 1.73 & 7 \\
\hline 1999 & 1527337 & 9.56 & 38 \\
\hline 2004 & 1931201 & 12.37 & 50 \\
\hline 2009 & 2945829 & 16.66 & 67 \\
\hline 2014 & 4091584 & 22.23 & 89 \\
\hline
\end{tabular}

Source: IEC and EISA Websites: http:/ / www.elections.org.za/ content/Elections/National-and-provincial-elections-results / http:/ / eisa.org.za/WEP/souresults2004.htm

Further to this the DA has retained its support base in the Western Cape, which it captured from the ANC in 2009. This is in contrast to the Inkatha Freedom Party (IFP) in KwaZulu-Natal, which lost the province to the ANC in the 2004 election. Table 2 depicts DA and ANC election results in the Western Cape over the last five elections.

Table 2

DA and ANC Election Results Western Cape 1994-2014

\begin{tabular}{|l|r|c|}
\hline Year & DA $\%$ & ANC $\%$ \\
\hline 1994 & 6.64 & 33.01 \\
\hline 1999 & 11.91 & 42.07 \\
\hline 2004 & 27.11 & 45.25 \\
\hline 2009 & 51.46 & 31.55 \\
\hline 2014 & 59.38 & 32.89 \\
\hline
\end{tabular}

Source: IEC and EISA Websites: http: / / www.elections.org.za/ content/Elections / National-and-provincial-elections-results / http: / / eisa.org.za/WEP/ souresults2004.htm

Do the DA's electoral successes suggest a strengthening of opposition politics in South Africa? Does the DA meet the obligations of an opposition party with regard to providing an institutional space for counter-political elites to organise and offer a viable alternative to the ruling party together with facilitating debate over political issues and public policy while also performing an oversight role 
(Jung \& Shapiro 1995)? This article considers these questions in the light of the 2014 election results. It begins with a brief background to the DA, then considers the role of opposition parties in a democracy, as posed by Courtney Jung and Ian Shapiro, linking this to an assessment of the DA's electoral gains.

\section{BACKGROUND}

The DA has its roots in liberal South African politics, centred, during the apartheid era, in the Progressive Party (PP). The PP (later the Progressive Federal Party - PFP) was a persistent parliamentary critic of apartheid policies. Following an amalgamation with other liberal parties and splinter groups the PFP was constituted as the Democratic Party (DP) in 1989. After the transition to democracy the DP formed an alliance with the New National Party (NNP) in 2000 and changed its name to the DA. The alliance suffered various setbacks, however, resulting in a group of senior NNP members breaking away to join the ANC in 2004.

The former leader of the DA, Tony Leon, is thought to have built a foundation for vocal opposition politics, while his successor, Helen Zille, has the task of repositioning the party away from being merely an opposition party to becoming a 'party of the government'(Southern 2011, p 283).

Tony Leon's 1999 'Fight Back' campaign was designed to appeal to minority concerns and encourage them to participate in politics. It stressed the party's dedication to political opposition and its consistent record of refusing to cooperate or align with the ANC. In this sense it would 'fight back' against crime and against policies affecting minorities, such as affirmative action. The campaign resulted in the DA strengthening its white-based support among middle-class Englishspeaking South Africans and absorbing former supporters of the NNP, but failing to make significant inroads into black, coloured and Indian communities (Jolobe 2009, p 134). In 2006, at a DA federal council meeting, it was noted that the party could only grow as a political force if it increased its support among black voters. The council noted that the party had so far failed to articulate any of the concerns of this constituency (Jolobe 2009, p 136).

Under Zille's leadership this led to the DA working to revamp its image to appeal to all South Africans, regardless of race and ethnicity. The revamp included using various patriotic symbols such as the South African flag, images of crossracial groups of people and employing all 11 national languages (Southern 2011, p 287). Election campaigns involved the use of struggle songs and chants as well as the invocation of struggle stalwarts such as Mahatma Gandhi and Nelson Mandela (Jolobe 2014, p 58). The party also worked on changing the racial composition of its leadership, promoting young black leaders to key party positions. Added to this the campaigns of 2009 and 2014 were significantly broadened to include a focus 
on eradicating poverty, providing education and health, fighting corruption, incentivising job creation and distributing shares to ordinary people to increase competition and bring down prices (DA election manifestos 2009 and 2014).

The 2014 election manifesto, for example, focused on the DA's pro-poor concerns, claiming that $76 \%$ of the Western Cape budget is spent on poor communities, that matric pass rates in the poorest schools in the Western Cape have increased from $56.9 \%$ to $73 \%$ and that $99.1 \%$ of households have access to piped water, $93.4 \%$ to electricity and $96.9 \%$ to sanitation. The manifesto also claimed that the city of Cape Town has 'the smallest gap between rich and poor of any city in the country' (DA Election Manifesto 2014, p 3). Election results in 2009 suggest that the DA, while making inroads in majority coloured communities in the Western Cape, still failed to increase its support among black voters (Jolobe 2009). The results in 2014, however, suggest that the party has started to attract black voters, though not at a rate that would threaten ANC hegemony (Jolobe 2014).

The DA's rise to power in the Western Cape was evident in the 2006 local elections, where it ran a close race with the ANC, securing 285 council seats to the ANC's 315, but attaining plurality in Cape Town, with $42.7 \%$ of the vote and 90 out of 210 council seats (Jolobe 2009, p 136). Because the ANC did not achieve controlling majorities in most of the municipalities in the Western Cape there was a proliferation of municipal-based coalitions in the province.

In the city of Cape Town the DA entered into a six-party coalition, which was only secured later, when it was joined by the Independent Democrats (ID) (Jolobe 2009). In the 2009 election the DA secured the province with $51.46 \%$ of the vote, which increased to $59.38 \%$ in 2014. Its support base in the city of Cape Town also grew between 2009 and 2014 - from 50.9\% to 59.3\% (Jolobe 2014, p 68). Indeed the DA's electoral support grew in most major cities between 2009 and 2014.

\section{THE ROLE OF OPPOSITION PARTIES}

The DA constitution endorses an independent and effective opposition, loyal to the constitutional order, as essential to the promotion and preservation of democracy (Democratic Alliance Federal Constitution 2012, s 1.2). The party further pledges itself to 'being an effective opposition when not in government' (Democratic Alliance Federal Constitution 2012, s 1.5.2.4). In Polyarchy, Participation and Opposition Robert Dahl argues that opposition, rivalry or competition between a government and its opponents is an important aspect of democratisation. A key characteristic of democracy is the continuing responsiveness of government to the preferences of its citizens, facilitated by opportunities for citizens to formulate their preferences, communicate these preferences through individual or collective 
action and have these preferences weighed equally in the conduct of government (Dahl 1973, p 2).

Stressing the importance of opposition in democratic politics Courtney Jung and Ian Shapiro (1995, p 272) argue that the role of opposition is threefold. The first is functional in that should a government lose an election there is the possibility of a peaceful handover of power among elites. Opposition parties are therefore sites for counter-elites to form and campaign as potential alternative governments. Should opposition parties not be perceived as realistic alternatives to the government of the day, the possibility of turnover is diminished and crises for the government are likely to become crises for the democratic state.

The second role of opposition is to legitimise the democratic political order. In this sense institutional space is created to ensure that discontent and dissatisfaction can be directed at the government of the day rather than at the democratic regime itself. So, the right to criticise and compete against the government, to influence legislation and the bureaucracy and to seek recourse through the courts is not forfeited.

The third role of opposition is to ensure the presence of healthy political debate. Opposition encourages competition over ideas among elites and counterelites, which leads to demands for reason-giving and coherence in public debate. This, in turn, empowers groups or individuals who have an interest in 'asking awkward questions', 'shining light in dark places' and 'exposing abuses of power'.

\section{CONSOLIDATION OF OPPOSITION?}

The DA's steady electoral gains are impressive in the context of South Africa's dominant- party democracy but do they signify a genuine consolidation of the DA's opposition status? In the run-up to the 2009 election 27 municipal ward seats were contested in by-elections in the Western Cape. These were the result of internal ANC factional conflict, which led to it vacating some seats and having its members expelled from others. The DA was therefore able to make significant gains at the local level in the province. These gains included the city of Cape Town, rural municipalities Citrusdal, Drakenstein and Theewaterskloof, the coloured township of Mitchells Plain and the white lower-middle-class area of Parow (Jolobe 2009: 139). The gains were built on in the 2009 election, when the DA won a majority in the Western Cape, winning $51.46 \%$ of the vote and becoming the first post-apartheid opposition party to win a majority in the Western Cape. Significantly, the ID seemed to be losing members of its coloured support base to the DA, polling only $4.68 \%$ of the vote in the province (Akokpari, 2009, p 189). Likewise, the Congress of the People (Cope) had failed to live up to opposition expectations, polling only $7.74 \%$ of the vote in the province (Akokpari 2009, p 189). 
In the city of Cape Town DA support was $50.9 \%$ compared with the ANC's $32.8 \%$. The DA also had a good showing in Mitchells Plain (80.9\%) (Jolobe 2009, p 145), as well as in the coloured majority suburbs of Belgravia Estate, Crawford, Grassy Park, Kensington and Lavender Hill. It also made gains in Manenburg, but not in Gugulethu, Langa, Khayelitsha, Mandela Park or Victoria Mxenge, which remained ANC strongholds, as did black majority suburbs such as Nyanga, Philippi, Imizamo Yethu and Samora Machel.

Nationally the DA increased its portion of the national vote by $16.7 \%$ and recorded growth in every province: by $37.6 \%$ in the Eastern Cape, $39.8 \%$ in the Free State, 28.3\% in Gauteng, 39.3\% in KwaZulu-Natal, 26\% in Mpumalanga, $36.7 \%$ in the North West and $44 \%$ in the Northern Cape (Jolobe 2009, p 143). Of the 1014628 new votes it received, however, 43\% came from the Western Cape and a further 211816 from the northern suburbs of Johannesburg. Support for the DA in major black townships across South Africa was minimal (Habib \& ShulzHerzenberg, 2011, p 195). The 2009 election results suggest that the DA was able to retain its original white middle-class support base (Kotze 2001) and consolidate support among the coloured constituency, but did not make significant gains in attracting the support of black voters.

The DA made further gains in the 2011 local government elections, performing strongly in Cape Town, Johannesburg, Tshwane and Nelson Mandela Bay. It had also entered into an agreement with the ID, following which ID leader Patricia de Lille joined the Western Cape DA provincial cabinet and later served as DA mayor of Cape Town. In the 2014 election the DA maintained control of the Western Cape with $59.38 \%$ of the vote. It gained over a million new national votes, going from 2945829 in 2009 to 4091548 in 2014 (Jolobe 2014, p 67) and increasing its vote in most metropolitan areas. It further unseated the IFP as official opposition in KwaZulu-Natal, where it increased its share of the Indian vote, attracting members of the Minority Front (MF) and making inroads into former MF strongholds such as Chatsworth. In this sense the DA's gains in Indian support could be linked to the weakening of the MF.

The DA also became the official opposition in the Eastern Cape, Mpumalanga, Northern Cape and Free State and strengthened its opposition status in Gauteng from $21.86 \%$ in 2009 to $30.78 \%$ in 2014 (Quintal 2014). Most importantly, it claimed to have attracted 760000 black votes, a figure arrived at 'using 2011 census data and its own ward profiles' (Whittles 2014). A close look at the DA's performance in black constituencies in Cape Town reveals, however, that these gains are minimal. In Site C Khayelitsha, for example, the party's vote share only increased from $0.2 \%$ to $1.1 \%$ and similar results were recorded in sections of Gugulethu and Philippi (Jolobe 2014, p 67). 
Other metropolitan areas, such as Nelson Mandela Bay, Johannesburg and Tshwane, followed the same pattern. What this does suggest, however, is that the DA has begun to become more visible in black constituencies. This is evident also in the campaigning tactics of some of its leaders. The party's then national spokesman, Mmusi Maimane, for instance, vigorously toured townships in Gauteng (Munusamy 2013). If the DA is increasing its support among black voters it is questionable whether it is, in fact, drawing them away from the ANC. As has been pointed out, even if it is, the numbers are not sufficiently high to threaten the ANC's hegemony (Jolobe 2014, p 57). Indeed, Collette Shulz-Herzenberg (2014, p 28) shows that despite continued growth and the fact that the DA remains the only opposition party to have increased its vote share, its support, in general, among all eligible voters has grown slowly over the past 20 years and accounts for only $13 \%$ of the voting-age population (VAP).

\section{AN ALTERNATIVE TO THE RULING PARTY?}

A consistent explanation for the DA's inability to appeal to black voters and establish itself as a viable opposition force or a site for counter-elites to form and campaign as potential alternative governments (Jung \& Shapiro 1995) is that voting in South Africa takes place along racial lines. In this sense, political activities and electoral preferences are determined by South Africans' racial location in society and based on 'identities', in the sense that allegiance is determined by voters' perceptions of who speaks for them rather than by policy preferences or the content of party programmes (Giliomee \& Simkins 1999; Friedman 2009, 2014).

Indeed, a 2011 Afrobarometer survey, based on a nationally representative random sample of 2399 South Africans, found that $44 \%$ of respondents identified with the ANC and 10\% with the DA. The survey revealed that the DA draws supporters mainly from urban areas and the ANC, while also drawing from urban areas, has a large following in rural settings. Furthermore, $56 \%$ of respondents who identified with the DA speak Afrikaans and one-third speak English, while those identifying with the ANC speak all official languages, with isiZulu (24\%) and isiXhosa $(23 \%)$ in the majority.

Survey results also showed that $29 \%$ of DA identifiers went on to postmatric studies while only $7 \%$ of ANC identifiers did likewise. The DA profile also indicated that $83 \%$ of its identifiers have never gone without food while the figure in this category is lower for the ANC, at 59\% (Graham 2012).

A recent City Press examination of voting demographics revealed that voting in the 2014 election seemed to take place along racial lines. Athlone in Cape Town, for example, has a $93 \%$ coloured population, $89.14 \%$ of which voted for the DA. The Indian population of Chatsworth in Durban is $92.5 \%$, of which $25.3 \%$ voted 
for the MF while $89.14 \%$ voted for the DA. The predominantly black population of Dobsonville, Soweto (99.2\%), voted predominantly for the ANC (76.15\%). Likewise, the majority white population of Waterkloof in Pretoria (69.1\%) showed a 72.3\% support for the DA (City Press, 11 May 2014).

Another rather obvious reason why the DA has been unable to attract a strong following among black voters is that it is simply not perceived by the majority of the electorate as a realistic alternative to the government of the day. A survey of 3009 respondents between the ages of 15 and 34, carried out in April 2013, found that $52 \%$ of black respondents believed that the DA would bring back some form of apartheid and $26 \%$ of Indians, $21 \%$ of coloureds and $19 \%$ of whites shared the view that if victorious in an election, the DA would bring back apartheid (Mail $\mathcal{E}$ Guardian, 23 April 2014). This distrust has, to an extent, been compounded by perceptions of the DA and by the party's confusing stance on critical policy issues.

The 'Know Your DA' campaign launched ahead of the 2014 elections aimed to eradicate this distrust. Its strategy was to 'wrestle control of the DA's narrative from other parties' and give it some measure of 'struggle credential'. To this end it featured the role of the Progressive Party and Helen Suzman in opposing apartheid and Zille's own opposition to apartheid in her journalistic capacity, in which she exposed the reasons for the death of Steve Biko in custody, as well as the fact that she had sheltered anti-apartheid activists from the police (Davis 2013). This tactic was not received very well, however, with a regular DA blogger arguing that it attempted to equate becoming a politician or 'freedom fighter' out of choice with the long struggle of black people for their humanity and dignity.

'Many black people like me,' he wrote, 'are in shock and utter disgust' (Cibane 2014). There were similar negative reactions to the party's views on black economic empowerment (BEE). A large DA poster in Johannesburg showing a smiling black man in a safety hat with the caption: 'We support BEE that creates jobs not billionaires' was deemed insulting to black people and, it was argued, suggests that the DA would prefer to see black South Africans as 'labour, not as owners of the means of production' (Hlongwane 2013).

The DA's stance on the policy issues that have the greatest impact on the voters it is trying to attract has also been confusing and a possible contributing factor to its alienating a broader support base. This was particularly the case with the Employment Equity Amendment Bill which deals with demographic diversity in the work place. In October 2013 the DA voted in favour of the Bill in the National Assembly but a couple of weeks later withdrew its support. In a newsletter entitled 'A plane crash that should have been avoided', Zille said the turnabout was due to the party 'dropping the ball'. She explained that the DA could not support legislation that is based on racial coercion ... will 
undermine growth, reduce jobs, drive away investment and work against black empowerment'. Using the metaphor of a plane crashing, she likened the incident to a lack of 'communication' and 'teamwork' (Zille 2013). According to media reports the turnabout caused some friction between Zille and DA parliamentary leader Lindiwe Mazibuko, who has argued for a stronger stance within the party on black economic empowerment and affirmative action (Pressly 2013).

Indeed, reports surfaced of a face-off between black leaders in the DA (the 'black caucus') and the 'old guard' on the issue (Makinana, Mataboge \& Pillay 2013). A number of black DA members argued that they were uneasy about the party's approach to affirmative action and believed it to be confusing voters, especially given that 'these two bills are the most important to the black people we are targeting'. Zille maintained that 'There is nothing progressive about coercion that reinforces racial quotas determined by unelected officials. It's Verwoerdian social engineering' (Makinana, Mataboge \& Pillay 2013).

The incident resulted in the defection of eight DA councillors to the ANC, suggesting that the loyalty of black DA supporters might still be precarious (Lodge 2014). Indeed, the DA faced a barrage of criticism from various quarters for its initial support of the Bill. The South African Institute of Race Relations stated that it was 'betraying the non-racial principles for which it historically stood'. Former DA leader Tony Leon commented (by tweet) that the Bill is 'illiberal, racially coercive and anti-economic growth' (Politics Web, 10 November 2013). In his newspaper column Leon (2013) maintained that the DA was 'scared of having the race and anti-transformation labels stuck to it' and added that should the party support the Bill 'we just have two versions of the ANC and voters no longer have a real choice' (Politics Web, 10 November 2013).

The question whether the DA offers a genuine alternative is pertinent with regard to its policies towards the poor and among 'service delivery' protesters. The Cape Town 'toilet wars' suggest that among residents of Cape Town's informal settlements perceptions of the DA are decidedly negative. A series of protests in Cape Town in 2013 involving the throwing of human waste on the steps of the legislature, at the airport and on the N2 highway in opposition to sanitation conditions among the poor are significant. The sanitation system in contention is portable toilets, which the Western Cape provincial secretary of the SA Youth Council compared with apartheid's 'tshemba' toilets or the 'bucket system', 'an affront to the human dignity of black people' (Robins 2013). Zille was personally targeted during a visit to Khayelitsha in June 2013 when protesters, unperturbed by police presence, poured human waste over the car she was travelling in.

What must have been more disturbing for Zille were placards which read 'Zille must not come here with a legacy of apartheid in our Ward 98. Can you 
relieve yourself in a bucket as a human being?' (Mposo 2013) and comments such as 'Enough is enough, the bucket toilets are the DA's way of bringing back apartheid ... We want to show the whole world that the city is not providing services to black people' (Mposo 2013).

The 'poo protests' were a continuation of ongoing 'toilet politics' in Cape Town. In 2011 a judgement was handed down in the Western Cape High Court stating that the city of Cape Town had violated the right to dignity. The city had constructed 1316 unenclosed toilets in Makhaza, Khayelitsha, claiming that it had an agreement with residents that they would build the enclosures themselves. The court held that the unenclosed toilets were inconsistent with the mayor's and the city's constitutional duty to provide the poorest of the poor with their basic needs (IOL News 29 April 2011).

The Social Justice Coalition (SJC) argued that the construction of open toilets reflected the dire lack of meaningful communication between the city and the inhabitants of Cape Town's informal settlements (Mail \& Guardian, 27 October 2010), while the DA claimed that the African National Congress Youth League (ANCYL) had initiated the campaign to discredit it (Templehoff 2012). A 2014 South African Human Rights Commission report found that the city's long-term use of temporary sanitation facilities violated the rights of Cape Town's poor and working-class communities. The investigation resulted from a complaint by the SJC, which opposed Cape Town's outsourced chemical toilets service plan (Social Justice Coalition Press Release, 16 July 2014).

'Service delivery' protests are by no means confined to the Western Cape - they are a feature of South African local politics all over the country. But the toilet wars suggest that Cape Town protesters don't believe a DA-led government has much more to offer the poor and working classes than one led by the ANC. Further to this point, it seems that protesters believe they have more recourse with the ANC than with the DA.

Protest opposing poor services and again, open toilets, in ANC-governed areas such as Rammulotsi township in the Free State province in 2011, for example (Templehoff, 2012), directed frustrations at local level management rather than directly at the ANC.

Protesters in Cato Manor, Durban, summed the position up this way: 'There's no challenge to the ANC. We don't, for example, want the DA in power. We were born and bred ANC we don't want another home' (Interview with Cato Manor protesters, 26 September 2013, Cato Manor). For all intents and purposes, therefore, it would seem that the DA is not perceived as a realistic alternative to the government of the day, thus reducing the possibility of electoral turnover (Jung \& Shapiro 1995). 


\section{A VIABLE OPPOSITION SPACE?}

So, if the DA is not considered a viable alternative to the ruling ANC does it serve as a possible institutional space for dissatisfaction to be directed at government rather than at the democratic order (Jung \& Shapiro 1995)? Its near merger with AgangSA and the fact that it received support from the shack dwellers' movement, Abahlali baseMjondolo (Abahlali), ahead of the 2014 election are useful ways of considering this.

In late January 2014 the DA announced that Agang would be integrated into the party and that its leader, Mamphela Ramphele, would be the DA's presidential candidate. Ramphele was quoted as saying, 'When we started Agang we said we are very anxious to see a rearrangement in South African politics ... the country is hungry for change.' (Mail E Guardian, 28 January 2014). The merger was, however, short lived. In early February the DA announced that Ramphele had reneged on her commitment to incorporate Agang's branches and members in the DA and to serve as the DA's presidential candidate (Mail $\mathcal{E}$ Guardian, 3 February 2014). Ramphele explained that 'millions of South Africans would not vote for the DA' because 'people are trapped in race-based politics' (Mail E Guardian, 3 February 2014). The ANC noted that the DA's attempt to 'rent a black' had lost it credibility, while further affecting the credibility of Agang (Mail \& Guardian, 3 February 2014).

The failed merger suggests two things. The first is that the DA doesn't seem very committed to its own black leadership in that it promoted someone from outside the party to stand as presidential candidate rather than favouring someone from inside the party, especially given that there are many eligible candidates.

Under Zille various young black people had been promoted to key leadership positions within the party. Among them were parliamentary leader Lindiwe Mazibuko, national spokesman Mmusi Maimane, chairman of south Gauteng Khume Ramulifho, chairman of north Gauteng Solly Msimanga, city councillor Johannesburg Makashule Gana and eThekwini city councillor Mbali Ntuli. The failure to appoint one of them as the party's presidential candidate contradicts the DA's contention that it is a party where members can rise to the top on the basis of merit (Friedman 2014a).

Secondly, the failed merger suggests that the DA is not viewed as a viable institutional space from which to challenge the ruling party. Agang pledged itself to abide by South Africa's founding democratic values but also to make good on the promises made by that democracy: 'After nearly twenty years the country's leaders have failed to deliver on the promise of freedom' (Ramphele Launch Speech, 22 June 2013).

Since Agang had started as a 'platform' and had later formally constituted itself as a political party the decision to merge with the DA was probably made 
to strengthen the movement. After having 'learned to listen to her members', however, Ramphele concluded that 'a white party remains white' (Mail E Guardian, 3 February 2014). Added to this Ramphele noted that the English-speaking white supporters of the DA could not understand the inequities visited on the majority of black South Africans and that the DA was complacent and trapped in its inability to realise that poverty can be eradicated (Ramphele 2013). The implication is that the DA is unlikely to deliver on democracy and the promises of freedom in South Africa because those to whom the promises have been made are unlikely to support the DA in an election.

This contention is supported by comments made by $S^{\prime}$ bu Zikode, leader of Abahlali in KwaZulu-Natal, when he explained his movement's decision to endorse the DA in the 2014 election. Abahlali has long been known for its 'no vote' campaign. He argued that ' $[w]$ e do not agree with the DA fundamentally on many core issues. This decision is not one that is based on ideology. Poor people do not eat ideology. Nor do they live in homes that are made out of ideology' (Tshabalala 2014). Abahlali's decision to support the DA was strategic and designed to 'weaken' the ANC and 'vote it out of power'.

An Abahlali activist interviewed in Durban explained that 'some of our members feel that we should [in elections] remove the ANC just to show them that they are not bigger than the people' (Interview with Abahlali activist, 13 March 2014, Durban). When asked, however, if this meant possible support for the Economic Freedom Front (EFF) as the new player in the field with a more pro-poor policy leaning, the activist said: 'The EFF is not an option, just like the NFP (National Freedom Party), it's one of those born yesterday, die tomorrow parties. It would be like throwing your vote in the bin' (Interview with Abahlali activist, 13 March 2014, Durban).

The implication here seems to be that the DA is considered to have some staying power as an opposition party and would, for this reason, be the best strategic choice. Furthermore, the DA engaged with Abahlali 'courteously' and has probably been easier to approach than the ANC, given the history of clashes between the ruling party and the shack dwellers movement in Durban. But Zikode is clear: 'Our endorsement of the DA does not mean that we are now members of the DA' (Tshabalala 2014).

Not all Abahlali members were comfortable with the decision to back the DA. Western Cape branch members pointed out that the DA-run city of Cape Town treats shack dwellers 'with contempt' (Knoetze 2014). Abahlali's endorsement of the DA, therefore, suggests temporary strategic action rather than any potential long-term alliance or a continued institutional space for directing discontent and dissatisfaction at the government (Jung \& Shapiro 1995). Indeed, Abahlali 'advances the politics of the poor and working class ... [by] build[ing] inside and outside of the electoral space ... a politics of dignity not a politics of power' (Tshabalala 2014). 


\section{OVERSIGHT STRATEGIES}

The DA has a good record of encouraging competition over ideas among elites and counter-elites, which leads to demands for reason-giving and coherence in public debate as well as to oversight (Jung \& Shapiro 1995). This is particularly the case with regard to corruption in the public sector. Of course, it is a useful springboard for the party to advertise its own record of unqualified audits for the city of Cape Town.

In a 2013 press release, the DA stated that South Africa had dropped down the Transparency International Corruption Perception Index. It noted that irregular expenditure in national departments had doubled, from R11-billion in 2009 / 2010 to R22.1-billion in 2010/2011 and R28.3-billion in 2011/2012. Also, wasteful expenditure had tripled from R437-million in 2009 to R1.5-billion in 2010/2011 and R1.8- billion in 2011/ 2012 (DA Press Release, 2013). The DA's position is that the government has done very little to reduce corruption and that the president himself has been involved in corruption and has managed to avoid accountability.

Among several incidents of corruption linked to President Zuma the DA listed the R206-million 'security upgrades' to his private home in Nkandla and the illegal landing at Waterkloof Airbase of a private aircraft carrying guests to the wedding of a member of the wealthy Gupta family, known to be intimates of the president. The DA is still trying to ascertain reasons for the fact that more than 700 charges of corruption and fraud involving President Zuma were dropped.

The party has used various processes to bring the perpetrators to account. In the case of the Nkandla investigation by the Department of Public Works, which was not released to the public, it filed a Promotion of Access to Information Application (PAIA), which was unsuccessful. It then took the matter to the Western Cape High Court (Makinana 2013). In relation to the Gupta scandal, the DA requested Parliament to establish an ad hoc committee to investigate the incident, but the request was denied (Mail \& Guardian, 15 October 2013).

The DA's probe into the suspension of the corruption charges against President Zuma included a lengthy pursuit of the records that had led to the suspension of the charges in 2009. In 2011 the High Court ruled in favour of the National Prosecuting Authority (NPA), who argued that the decision was not eligible for review and that the DA had no locus standi in the matter as its interests were party political and not legal (Mail \& Guardian, 15 February 2012). The DA appealed and the five-year court battle culminated in 2014, when, after six court applications, the Supreme Court of Appeal ordered the NPA to hand over the 'spy tapes' at the centre of the decision and full records pertaining to the decision to drop the charges (Rabkin 2014). 
The DA's focus on accountability for corruption is impressive in that it has utilised various mechanisms and processes to expose illegalities and call for accountability. It does so, however, in the context of a free press, which has a record of exposing corruption, and in the context of functional Chapter 9 Institutions such as the Public Protector. Other opposition parties, among them the EFF and Cope, have also played a significant oversight role with regard to the ruling party. In this sense the DA is but one of the spaces for 'asking awkward questions', 'shining light in dark places' and 'exposing abuses of power' (Jung \& Shapiro 1995).

\section{CONCLUSION}

This article argues that the DA's electoral gains do not necessarily reflect a strengthening of opposition politics in South Africa. This is mainly owing to the fact that the DA, despite its steadily increasing electoral support, shows little sign of attracting a large enough constituency amongst black voters. In large part, and in the context of the role of the opposition according to Jung \& Shapiro, this is because the DA is not viewed as a realistic enough alternative to the ruling party, nor is it considered by those who oppose the ANC as a viable opposition space.

The DA's limitations in constituting a genuine alternative to the ruling party can be linked to the voting patterns of South Africans, which still occur along racial lines, with a majority of voters identifying more closely with the ANC. Various perceptions of the DA as a 'white' party which would 'bring back apartheid' further compound these limitations, as does the party's stance on policy issues such as the Employment Equity Bill, which would have a negative impact on its minority constituencies but further national goals of transformation.

In terms of the DA as a viable opposition space, both its near merger with Agang and the nature of its endorsement for the 2014 elections by Abahlali suggest that it is still viewed with some suspicion and constitutes, at best, an uncomfortable space for directing dissatisfaction towards the ruling party. The DA does, however, contribute to overseeing the government, using various mechanisms to this end, and the 'spy tapes' incident is an example of this. This goes some way to furthering healthy political debate, demanding accountability and encouraging competition over ideas among elites and counter-elites.

In the run-up to the 2016 local government elections the DA will no doubt continue its quest to move beyond the 'racial ceiling', but commentators argue that it has a number of internal challenges to deal with in the interim. Among these are its current lack of capacity, evidenced by advertisements of various vacancies among its parliamentary staff, compounded by the loss of leaders such as parliamentary leader Mazibuko, CEO Jonathan Moakes and federal youth leader Mbali Ntuli. 
The DA's 'strategic drift' is also likely to impede its attempts to consolidate itself as a genuine opposition force. Commentators argue that the party has placed too much focus on tactics, thus sacrificing long-term goals. These include its uncritical endorsement of the National Development Plan and its relentless 'get rid of Zuma' campaign. These tactics also suggest that the DA suffers from some uncertainty about its principles, its stance on affirmative action, being an example (Van Onselen, 2014).

\section{- REFERENCES}

Africa, C. 2009. Western Cape Election Update No 7. Johannesburg: EISA Election Update Series.

Akokpari, J. 2009. Western Cape Election Update No 8. Johannesburg: EISA Election Update Series.

Cibane, B. 2013. 'Know your DA insults blacks'. Mail \& Guardian, Thought Leader, 11 June. Available at: www.thoughtleader.co.za/bradcibane/2013/06/11/ know-your-da-an-insult/

City Press. 2014. 'Do we vote along racial lines?' Graphic, 11 May. Available at: www. scribd.com/doc/223280433/Do-we-vote-along-racial-lines

Democratic Alliance (DA). 2009. Election Manifesto 2009. Available at: www.da.org. za/docs / 6674/21941\%20DA\%20Manifesto\%20Eng.pdf

DA. 2012. Federal Constitution. Available at: www.da.org.za/docs/542/DA\%20

Federal $\%$ 20Constitution $\% 20$ approved $\% 20$ by $\%$ 20Congress $\% 2024 \% 20$ November\%202012.pdf

DA. 2013. 'Corruption perception index: corruption is on the increase in South

Africa'. Press Release (no date). Available at: www.da.org.za/2013/12/ corruption-perception-index-corruption-is-on-the-increase-in-south-africa/

DA. 2014. Election Manifesto 2014. Available at: www.da.org.za / docs/15652/DA\%20 Manifesto.pdf

Dahl, R. 1973. Polyarchy, Participation and Opposition. New Haven: Yale University Press.

Davis, R. 2014. 'Know your DA: A tale of two Helens'. Daily Maverick, 14 May. Available at: www.dailymaverick.co.za/article/2013-05-14-know-your-daa-tale-of-two-helens /

Friedman, S. 2009. 'Small telling things that the ANC would be foolish to ignore'. Business Day, 24 A pril. Available at: www. allafrica.com/stories / 200904240067. html

Friedman. S. 2014a. 'Ramphele's nomination will cause problems not votes'. Business Day, 30 January. Available at: www.bdlive.co.za/opinion/ 
columnists / 2014 / 01/30 / rampheles-nomination-will-create-problems-notvotes

Friedman, S. 2014b. 'The path of the past: South African democracy twenty years on'. Election Update No 2. Johannesburg: EISA Election Update Series.

Giliomee, H \& C Simkins (eds). 1999. The Awkward Embrace: One Party Domination and Democracy. Cape Town: Tafelberg.

Graham, P. 2012. 'Party identification in South Africa: Profiles for the ANC and DA'. Afrobarometer Briefing Paper No 108.

Habib, A \& C Shulz-Herzenberg. 2011. ‘Democratization and parliamentary opposition in contemporary South Africa: The 2009 national and provincial elections in perspective'. Politikon 38(2).

Hlongwane, S. 2013. 'DA's clumsy BEE poster misses its mark'. Business Day, 10 September. Availableat: www.bdlive.co.za / opinion/columnists/2013/09/10/ das-clumsy-bee-poster-misses-its-mark

IOL News. 2011. '29 DA's racism exposed:ANC', April. Available at: www.iol.co.za/ news / politics / da-s-racism-exposed-anc-1.1062858

Jolobe, Z. 2009. ‘The Democratic Alliance: Consolidating the official opposition'. In R Southall \& J Daniel (eds). Zunami. Cape Town: Jacana.

Jolobe, Z. 2014. 'The Democratic Alliance election campaign: "Ayisafani"'. In C Schulz-Herzenberg \& R Southall (eds). Election 2014. Pietermaritzburg: Jacana.

Jung, C \& I Shapiro. 1995. 'South Africa's negotiated transition: Democracy, opposition and the new constitutional order'. Politics $\mathcal{E}$ Society 23(2).

Knoetze, D. 2014. 'Abahlali chief spoiled vote in anger at DA'. IOL News, 12 May. Available at: www.iol.co.za/news/politics/abahlali-chief-spoiled-vote-inanger-at-da-1.1686754

Kotze, H. 2001. 'A consummation devoutly to be wished: The Democratic Alliance and its potential constituencies'. Democratization 8(1).

Leon, T. 2013. 'DA at sixes and sevens over racist employment bill'. Business Day, 5 November. Available at: www.bdlive.co.za/opinion/columnists/2013/11/05/ da-at-sixes-and-sevens-over-racist-employment-bill

Lodge, T. 2014. 'The 2014 South African general elections'. Electoral Studies 35.

Mail \& Guardian. 2010. 'Khayelitsha toilet saga rumbles on', 27 October. Available at: mg.co.za/article/2010-10-27-khayelitsha-toilet-saga-rumbles-on

Mail \& Guardian. 2012. 'DA's appeal against Zuma's corruption charges begins', 15 February. Available at: mg.co.za/article/2012-02-15-das-appeal-againstzumas-corruption-charges-begins

Mail \& Guardian. 2013. 'DA wants Parliament to investigate Zuma for role in Gupatgate', 15 October. Available at: mg.co.za/ article/2013-10-15-da-wantsparliament-to-investigate-zuma-for-role-in-guptagate

Mail \& Guardian 2014. 'Ramphele announced as DA presidential candidate', 
28 January. Available at: mg.co.za/article/2014-01-28-agang-sa-da-mergewith-ramphele-as-presidential-candidate /

Mail \& Guardian. 2014. 'Ramphele: DA-Agang merger a joint mistake', 3 February. Available at: mg.co.za/article/2014-02-03-ramphele-da-agang-merger-ajoint-mistake

Mail \& Guardian. 2014. 'Sample survey of young blacks believe DA would bring back apartheid', 23 April. Available at: mg.co.za/article/2013-04-23-studyshows-most-surveyed-young-blacks-believe-da-would-bring-back-apartheid Makinana, A. 2013. 'DA goes to court to access Nkandla report'. Mail \& Guardian, 30 September. Available at: mg.co.za/article/2013-09-30-da-goes-to-courtto-access-nkandlagate-report

Makinana, A, M Mataboge \& V Pillay. 2013. 'EE Bill: Is black the DA's new true blue?' Mail \& Guardian, 15 November. Available at: mg.co.za/article/201311-14-is-black-the-das-new-true-blue

Mposo, N. 2013. 'Faeces flung at Zille'. IOL News, 5 June. Available at: www.iol. co.za/news/politics/faeces-flung-at-zille-1.1527268

Munusamy, R. 2013. 'Election 2014: The ANC / DA high stakes pendulum'. Daily Maverick, 16 October. Available at: www.dailymaverick.co.za/article/201310-16-election-2014-the-ancdas-high-stakes-pendulum/

Politics Web. 2013. 'DA's u-turn on the EE Amendment Bill: A timeline', 10 November. Available at: politicsweb.co.za/politicsweb/view/politicsweb/en/page716 19 ? oid $=449824 \&$ sn $=$ Detail\&pid $=71619$

Pressly, D. 2013. 'Confusion over employment equity law divides DA'. IOL, 12 November. Available at: www.iol.co.za/business/features/confusionover-employment-equity-law-divides-da- 1.1605645

Rabkin, F. 2014. 'Spy tapes to be revealed soon'. Business Day, 29 August. Available at: www.bdlive.co.za/ national / 2014/08/29/spy-tapes-to-be-revealed-soon Ramphele. M. 2013. Address at the launch of Agang. Pretoria Events Centre, 22 June. Available at: www.polity.org.za/article/sa-mamphela-ramphele-address-byagang-south-africa-leader-at-the-offocial-the-launch-of-the-political-partytshwane-events-centre-pretoria-22062013-2013-06-22

Ramphele, M. 2013. A passion for freedom. Cape Town: Tafelberg.

Robins, S. 2013. 'Politicisation of human waste'. Cape Times, 27 September. Available at: www.iol.co.za/ capetimes / politicisation-of-human-waste-1.1583748

Social Justice Coalition. 'SAHRC finds city of Cape Town's lack of sanitation plan unreasonable and racially discriminating'. Release, 16 July. Available at: www.sjc.org.za/ posts/sahrc-finds-city-of-cape-towns-lack-of-sanitationplan-unreasonable-and-racially-discriminatory

Schulz-Herzenberg, C. 2014. 'Trends in electoral participation, 1994-2014'. In C Schulz-Herzenberg \& R Southall (eds). Election 2014. Pietermaritzburg: Jacana. 
Southern, N. 2011. 'Political opposition and the challenges of a dominant party system: The Democratic Alliance in South Africa'. Journal of Contemporary African Studies 29(3).

Templehoff, J W N. 2012. 'From Makhaza to Rammulotsi: Reflections of South Africa's "toilet election" of 2011'. Historia 57.

Tshabalala, S. 2014. 'Why Abahlali endorsed the DA: S'bu Zikode speaks to GroundUp'. GroundUp Newsletter, 5 May. Available at: groundup.org.za/ content/why-abahlali-endorsed-da-sbu-zikode-speaks-groundup

Quintal, G. 2014. 'ANC's Gauteng support takes a knock in 2014'. Mail \& Guardian, 10 May. Available at: mg.co.za/ article/2014-05-10-anc-support-in-gautengtakes-a-knock-in-2014-elections

Van Onselen, G. 2014. 'Cracks show as DA comes under pressure'. Business Day, 27 August. Available at: www.bdlive.co.za / opinion/columnists/2014/08/27/ cracks-show-as-da-comes-under-pressure

Williams, M. 2013. 'R2 billion welcome to Zumaville'. IOL News, 15 July. Available at: www.iol.co.za/news / politics / r2bn-welcome-to-zumaville-1.1546571

Whittles, G. 2014. 'Zille: DA gets 760,000 black votes'. Eye Witness News, 9 May. Available at: ewn.co.za/2014/05/09/DA-receives-760000-black-votes

Zille, H. 2013. 'A plane crash that should have been avoided'. DA Newsletter. Available at: www.da.org.za/2013/11/a-plane-crash-that-should-havebeen-avoided/ 